\title{
Summary Report: Assessment and Opportunity Identification of Energy Efficient Pollution Prevention Technologies and Processes
}

\author{
Prepared in Response to Section 2108 subsections (b) and (c) \\ of the Energy Policy Act of 1992
}

\author{
Propared by \\ Sandla Natlonal Laboratorles \\ Albuquerque, Now Moxlco 87185 and Llvermore, California 94550 \\ for the United States Department of Energy
}

under Contract DE-AC04-94AL85000

Approved for public release; distribution is unlimited.

\section{DISCLAIMER}

This report was prepared as an account of work sponsored by an agency of the United States Government. Neither the United States Government nor any agency thereof, nor any of their employees, makes any warranty, express or implied, or assumes any legal liability or responsibility for the accuracy, completeness, or usefulness of any information, apparatus, product, or process disclosed, or represents that its use would not infringe privately owned rights. Reference herein to any specific commercial product, process, or service by trade name, trademark, manufacturer, or otherwise does not necessarily constitute or imply its endorsement, recommendation, or favoring by the United States Government or any agency thereof. The views and opinions of authors expressed herein do not necessarily state or reflect those of the United States Government or any agency thereof. 
Issued by Sandia National Laboratories, operated for the United States Department of Energy by Sandia Corporation.

NOTICE: This report was prepared as an account of work sponsored by an agency of the United States Government. Neither the United States Government nor any agency thereof, nor any of their employees, nor any of their contractors, subcontractors, or their employees, makes any warranty, express or implied, or assumes any legal liability or responsibility for the accuracy, completeness, or usefulness of any information, apparatus, product, or process disclosed, or represents that its use would not infringe privately owned rights. Reference herein to any specific commercial product, process, or service by trade name, trademark, manufacturer, or otherwise, does not necessarily constitute or imply its endorsement, recommendation, or favoring by the United States Government, any agency thereof or any of their contractors or subcontractors. The views and opinions expressed herein do not necessarily state or reflect those of the United States Government, any agency thereof or any of their contractors.

Printed in the United States of America. This report has been reproduced directly from the best available copy.

Available to DOE and DOE contractors from

Office of Scientific and Technical Information

PO Box 62

Oak Ridge, TN 37831

Prices available from (615) 576-8401, FTS 626-8401

Available to the public from

National Technical Information Service

US Department of Commerce

5285 Port Royal RD

Springfield, VA 22161

NTIS price codes

Printed copy: A03

Microfiche copy: A06

Data gathering and report preparation occurred from May to August 1993. This report responds to Section 2108, subsections (b) and (c), of the Energy Policy Act of 1992. This report (SAND93-2122) is a summarization of the information and finding of a separate full report (SAND94-2568). The full report includes an expanded description of all findings as well as the information collected for the project. Since this work was completed, a report that responds to Section 2108 subsection (a) has been drafted. Information about this later report is available from Mr. Bruce Cranford, DOE/OIT/EE-22. 


\section{DISCLAIMER}

Portions of this document may be illegible in electronic image products. Images are produced from the best available original document. 


\section{Contents}

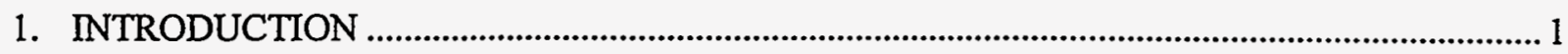

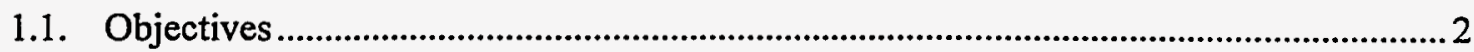

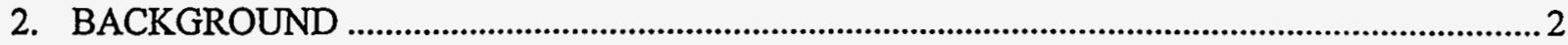

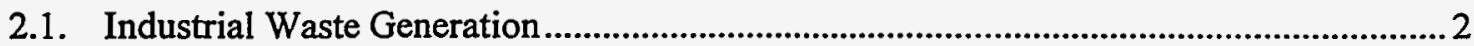

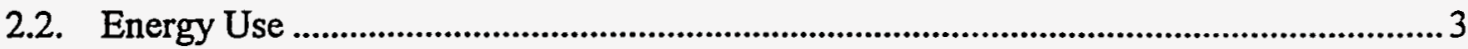

2.3. Economic Impacts of Waste Production ....................................................................... 4

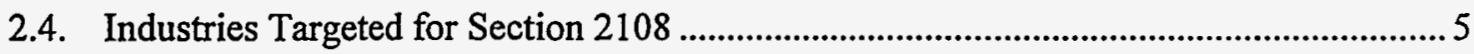

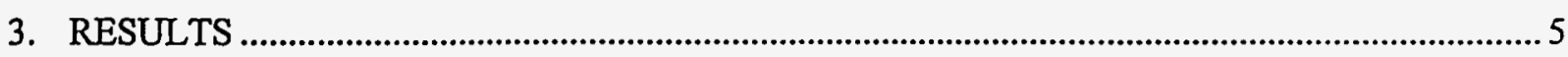

3.1. Identification of Opportunities (Subsection 2108(b)) .................................................5

3.2. Assessment of Technologies (Subsections 2108(c)(1) - (c)(6)) .................................. 6

3.2.1. Approach - Technology Assessments ....................................................... 7

3.2.2. Summary Findings ............................................................................................ 7

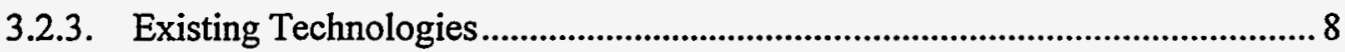

3.2.4. Current Use by Industry .................................................................................... 10

3.2.5. Developing Technologies \& Projected Availability ..................................... 11

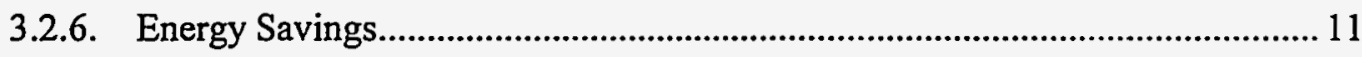

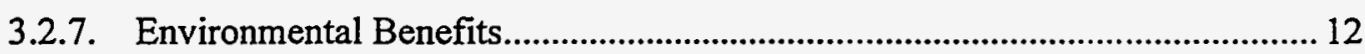

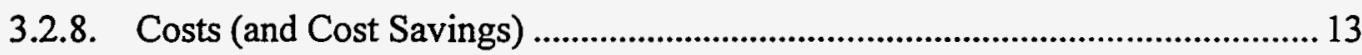

3.3. Evaluation of Barriers (Subsections 2108(c)(7) - (c)(8)) ............................................ 14

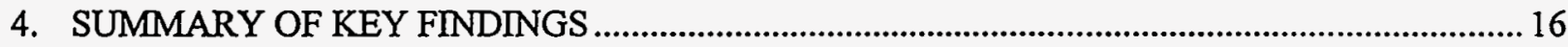

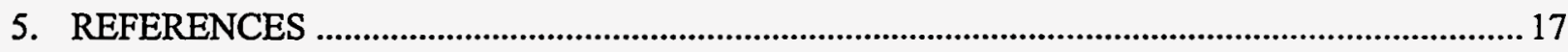


December 1993 


\section{INTRODUCTION}

On October 24, 1992, the President signed the Energy Policy Act of 1992 (EPAct, Public Law 102486). Section 2108, subsections (b) and (c), of EPAct requires the Department of Energy to identify opportunities to demonstrate energy efficient pollution prevention technologies and processes; to assess the availability and the energy, environmental, and cost effects of such technologies; and to report the results within one year. This report is in response to that requirement. ${ }^{1}$

As required by Section 2108 , this report was prepared in close consultation with the Environmental Protection Agency. It is based on literature searches and contacts with experts in industry, academia, and the research community. Information was collected and the report prepared between May and August 1993.

A full report that contains a background section describing industrial waste generation, energy use, and costs for pollution abatement, as well as a comprehensive presentation of results, a

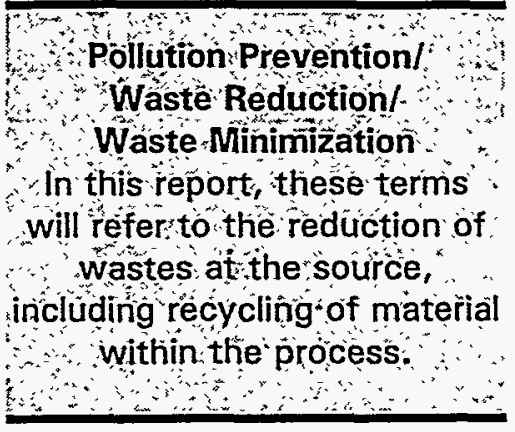
description of the individual technologies identified, and full references is available (SAND94-2568).

In addition to the above-described reporting requirements, Section 2108 , subsection (a), authorizes the DOE to continue to carry out a 5-year program to improve the energy efficiency and cost effectiveness of pollution prevention technologies and processes, including source reduction and waste minimization technologies and processes. National waste reduction efforts in both the private and public sectors encompass a variety of activities to decrease the amount of wastes that ultimately enter our air, water, and land. DOE's Office of Industrial Technologies (DOE/OIT) recognized the importance of these efforts and confirmed the federal government's commitment to waste reduction by establishing the Industrial Waste Program (IWP) in 1990. The program is driven by industry and national needs, and is working on new technologies and information dissemination that industry identifies as vital.

The national benefits of new technologies do not accrue to the economy until transferred to industry and incorporated into commercially available processes or products. The IWP has been designed with technology transfer in mind. Industry actively participates in both projects and program planning, thereby increasing the likelihood of commercialization and future participation. Academic participation in the IWP is also important, not only for the technical expertise of the nation's universities and colleges, but also in helping build the foundations for an intrinsic waste minimization outlook for future generations. In the relatively short time since inception, the IWP has already commercialized four significant energy efficient pollution prevention technologies that are now improving U.S. industry's productivity and competitiveness.

1 The Office of Technology Assessment is producing a report entitled Industry Technology and the Environment: Competitive Challenges and Business Opportunities, which will examine, in part, pollution prevention technology and its relationship to industrial competitiveness. This report should be released in January 1994. 


\subsection{Objectives}

This report addresses the requirements under Section 2108 subsections (b) and (c):

- Subsection (b) - identify opportunities to demonstrate energy efficient pollution prevention technologies and processes

- Subsection (c)(1) - assess technologies from Subsection (b) to increase productivity and simultaneously reduce the consumption of energy and material resources, and the production of waste

- Subsection (c)(2) - assess the current use of such technologies by industry in the U.S.

- Determine the status of technologies currently being

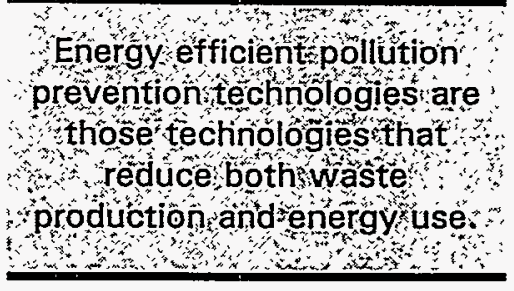
developed, including:

Subsection (c)(3) - projected commercial availability

Subsection (c)(4) - energy savings resulting from their use

Subsection (c)(5) - environmental benefits

Subsection (c)(6) - costs

- Subsection $(c)(7)$ - evaluate any existing federal or state regulatory disincentives for the employment of such technologies

- Subsection (c)(8) - evaluate other barriers to the use of such technologies

\section{BACKGROUND}

Identifying opportunities for the demonstration of energy efficient pollution prevention technologies and processes for the industrial sector is neither simple nor trivial. The industrial sector is the most complex and diverse segment of the U.S. economy. There are more than 360,000 industrial facilities in the U.S., using tens of thousands of processes with millions of different pieces of equipment and employing nearly 20 million people to make hundreds of thousands of products. These facilities consume large quantities of raw materials and energy resources every year. Their waste streams, as well as the technology options for preventing them, are very specific not only to individual industries, but even to plants within the same industry that produce similar products. The following sections look at: (1) the volume of waste produced by industry; (2) the amount of energy used by industry; and (3) the economics of pollution control expenses. This information makes a strong case for focusing the efforts of Section 2108 on a subset of industries that have the largest composite impact in these three areas.

\subsection{Industrial Waste Generation}

The total U.S. industrial waste stream is estimated to be more than 12 billion tons per year (Figure 2.1). Nonhazardous manufacturing wastes, estimated at 6.5 billion tons per year, account for roughly $50 \%$ of all industrial wastes, while hazardous wastes account for about $4 \%$. The remainder of industrial wastes comes from nonmanufacturing industries. 
The following are wastes included in Figure 2.1:

- Hazardous \& nonhazardous wastes as defined by the Resource Conservation and Recovery Act (RCRA)

- Toxic wastes defined by the Toxic Substances Control Act (TSCA) and reported in the Toxic Release Inventory (TRI)

- Metal and minerals mining wastes

- Oil and gas exploration \& production wastes

- Selected gaseous wastes

The following are wastes not included in Figure 2.1:

- Radioactive waste

- Municipal solid waste

- Infectious hospital waste

- Construction and demolition waste

- Utility waste

- Global warming gases

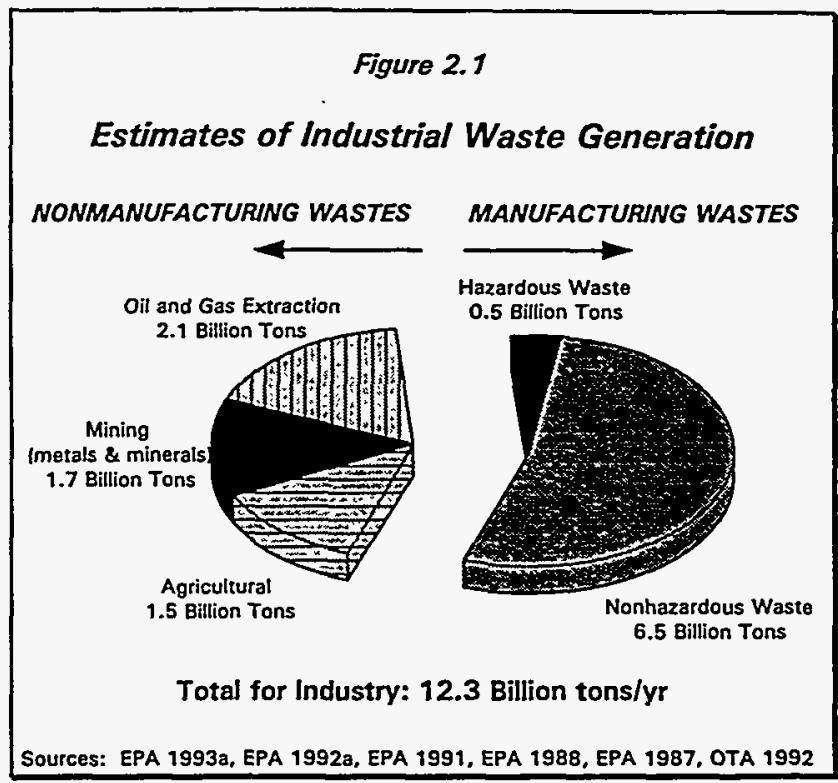

While the focus to date has been on controlling the pollution and wastes that are produced, there is increasing interest in reducing the wastes and pollution that are produced in the first place. Pollution prevention concepts are not new. For many years, certain industries have practiced pollution prevention and recycling when it made economic sense. For example, the metals industry has long since recycled home (produced at the point of base metal production) and prompt (produced at a subsequent manufacturing step) scrap metal. The trimmings from ingots as well as scrap associated with stamping round can lids from a rectangular sheet have been remelted and reused for years. Today, the steel industry produces about $65 \%$ of its annual output from the recycling of in-process and post-consumer wastes. DOE, EPA, and other federal agencies are endeavoring to extend pollution prevention concepts and practices, and place this long-term solution at the forefront of environmental management.

\subsection{Energy Use}

Industry accounts for nearly 31 quads $^{2}$, or $37 \%$, of all U.S. energy consumption (Figure 2.2), and most of this energy is used in the manufacturing sectors. The cost to industry for this energy is about $\$ 130$ billion per year.

Waste generation is often equated with energy use. When waste is produced, energy is almost always consumed at the same time. Each waste that is produced by an industrial process is associated with the use of energy, both for creation of the waste, and also for the ensuing handling, treatment, and disposal. When the waste that is generated is reduced, the energy that is used is decreased. This returns double in that a reduced need for energy means the waste products from energy conversion at

2 A "quad" is an energy unit equivalent to $1 \times 10^{15}$ Btu, or a quadrillion Btu. This is the energy used by about 9.5 million U.S. homes annually. 
the power plant are also diminished. Industrial waste reduction and decreased energy use are often interconnected.

\subsection{Economic Impacts of Waste Production}

The economic burden of waste production in industry is not well understood. Further, current accounting methods have not been able to capture its full costs. Production costs are affected by a wide range of factors such as materials use, energy use, labor productivity, capital productivity, environmental controls, and liability. The extent to which production and management of wastes, separate from products, influences the need for increased resources is not easily identified. Further, there are costs not associated with the

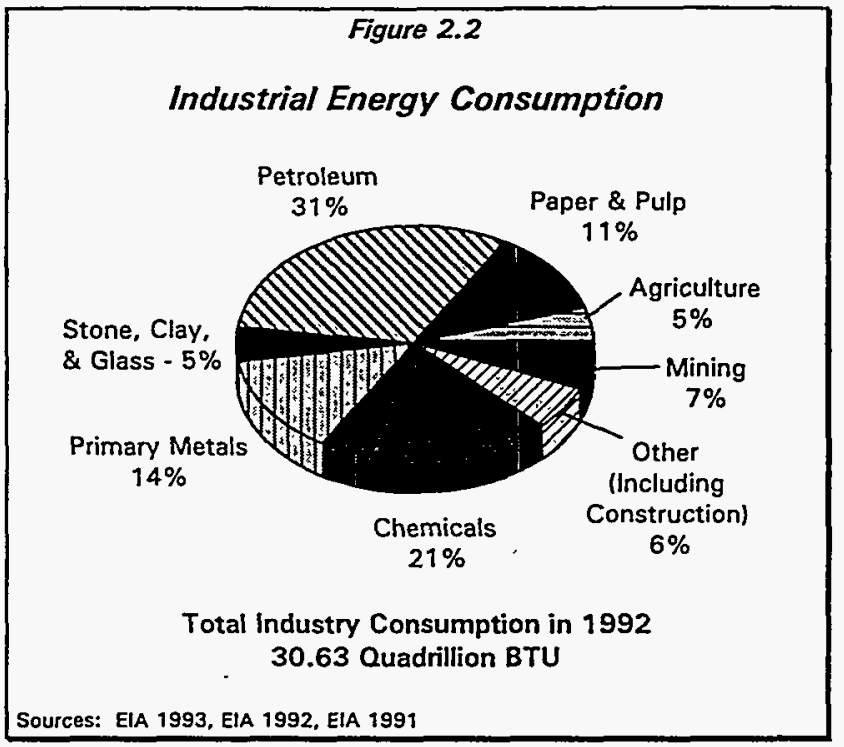
production process itself that may ultimately present a large hidden cost, for example, liability costs.

Pollution control expenditures are one aspect of waste production that can be examined. Estimates for the amount that industry spends on pollution abatement vary significantly. EPA estimated industry's share of control, treatment, and disposal cost to be more than $\$ 70$ billion in 1990 (EPA 1990). The Pollution Abatement and Control Expenditures survey estimates that manufacturers spent approximately $\$ 25$ billion on pollution abatement in 1991 (Figure 2.3). Most of these costs are related to toxic wastes, which are less than $1 \%$ of the -12 billion tons. At this time, there is no accurate estimate for the total cost to industry of the impacts of waste materials production.

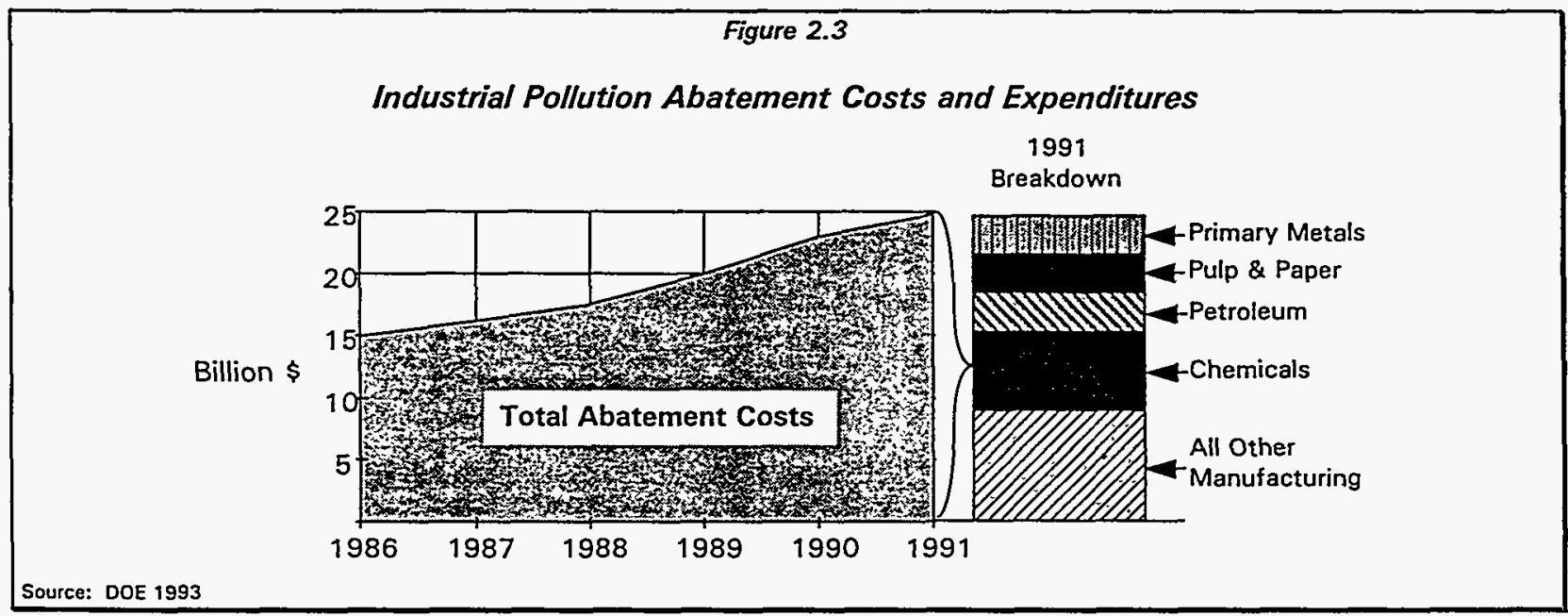




\subsection{Industries Targeted for Section 2108}

Given the complexity and diversity of U.S. industry, the focus of this report was limited to those industries with the most significant overall impacts and representing the greatest opportunities for industrial waste and energy reduction. The seven industry sectors targeted in this report are:

\begin{tabular}{|llr|}
\hline 1. & Agriculture & (SIC 1-9) \\
2. & Mining & (SIC 10, 13, 14) \\
3. & Pulp and Paper & (SIC 26) \\
4. & Chemicals & (SIC 28) \\
5. & Petroleum & (SIC 29) \\
6. & Stone, Clay and Glass & (SIC 32) \\
7. & Primary Metals & (SIC 33) \\
& \\
SIC $=$ Standard Industrial Classification codes as defined \\
by the Department of Commerce.
\end{tabular}

Of all industries with Standard Industrial Classifications 1-39, these 7 target industries collectively account for about:

- $\quad 94 \%$ of nonhazardous wastes (Figure 2.1)

- $\quad 94 \%$ of energy consumption (Figure 2.2)

- $\quad 73 \%$ of toxic releases (EPA 1992a)

- $\quad 95 \%$ of hazardous wastes (EPA 1993a)

- $\quad 92 \%$ of air pollutants (EPA 1991)

- $67 \%$ of pollution abatement costs (Figure 2.3)

\section{RESULTS}

The results included in this report are: (1) keyed to subsections of Section 2108; and (2) focused and classified by the seven industry sectors previously identified. Technology-based solutions associated with each industry, because of their specificity, are often developed, funded, and implemented by companies within that industry. Finally, most of the information and data in the open literature are presented along industry sector lines.

\subsection{Identification of Opportunities (Subsection 2108(b))}

\section{(b) - identify opportunities for the demonstration of energy efficient pollution prevention technologies and processes}

Opportunities for demonstration/development of energy efficient pollution prevention technologies and processes will continue to be identified by DOE/OIT. To date, such opportunities have been identified for the chemical and petroleum industries. The process of assessing opportunities started with the chemical industry prior to passage of EPAct and is summarized in the joint DOE/AIChE ${ }^{3}$ Report, "Report of the CWRT ${ }^{4}$ Workshop on: Waste Reduction Opportunities in Industry" (DOE 1991a). The

\footnotetext{
3 American Institute of Chemical Engineers.

4 American Institute of Chemical Engineers.
4 Center for Waste Reduction Technology.
} 
workshop identified the following higher priority technological areas with opportunities to exploit waste reduction in the production and use of chemicals (Table 3.1 ).

\section{Table 3.1 Chemical Industry - Highest Priority Technologies from Waste Reduction Opportunities Workshop}

1. Separation of dilute organics from water

2. Alternative in-process separation techniques for organic/inorganic/aqueous solutions

3. Emission control of dilute volatile organic compounds*

4. Total water reuse

5. Low-cost sorbent regeneration process

6. Post consumer recycling, upgrading, and separation*

* While this report is concerned with pollution prevention, the industrial panel results did include these two pollution treatment strategies.

In July 1993, a panel of petroleum industry representatives developed two rankings of opportunities for technology demonstrations important from a waste reduction and improved energy efficiency perspective. The two lists show the areas of opportunity first in their general order of relative importance, then in the order of relative importance for a government role in their demonstration (Tables 3.2 and 3.3).

\begin{tabular}{|ll|}
\hline & $\begin{array}{c}\text { Table 3.2 Petroleum Industry - } \\
\text { Order from Overall } \\
\text { Composite Ranking }\end{array}$ \\
\hline 1. & Wastewater management \\
2. & Advanced geophysical diagnostics \\
3. & Toxic air emissions \\
4. & Spent catalyst reuse \\
5. & Dry hydrogen sulfide adsorption \\
6. & Locating orphan wells \\
7. & Oil/water emulsion breaking \\
\hline
\end{tabular}

\begin{tabular}{|ll|}
\hline & $\begin{array}{c}\text { Table 3.3 Petroleum Industry - } \\
\text { Order Relative to Importance } \\
\text { of a Federal Role }\end{array}$ \\
\hline 1. & Toxic air emissions \\
2. & Locating orphan wells \\
3. & Wastewater management \\
4. & Advanced geophysical diagnostics \\
5. & Oil/water emulsion breaking \\
6. & Spent catalyst reuse \\
7. & Dry hydrogen sulfide adsorption \\
\hline
\end{tabular}

The generation of wastewater was the overriding theme of the opportunity sets identified by the chemical and petroleum industries. Air emissions involving toxic substances are another common concern cutting across both industries.

\subsection{Assessment of Technologies (Subsections 2108(c)(1) - (c)(6))}

Subsection 2108(c)(1) requires that an assessment be made for the technologies identified in subsection (b). To optimize the time and resources available to address the assessment requirements of Section 2108 , the focus to date has been on providing a foundation for addressing opportunity identification and subsequent assessment activities. This foundation is built on a systematic review of the literature for 
pollution prevention technologies which have, in turn, been evaluated relative to the information requested in subsection 2108 (c). This background will both provide an insight into the current state of pollution preventing technologies in industry and support future efforts to identify demonstration opportunities. The results derived from the open literature are summarized below.

\subsubsection{Approach - Technology Assessments}

The review of existing and developing technologies that involve waste reduction objectives encompassed the open literature and appropriate databases. In addition, knowledgeable individuals in government, universities, and other organizations were contacted, as well as trade association representatives in the targeted industry sectors and representatives of states with active pollution prevention/waste reduction technical assistance programs. Approximately 300 documents (reports, books, and journal articles) were collected and reviewed.

There are thousands of technologies currently under development, many of which may have positive impacts on waste reduction and energy efficiency.

Waste Reduction Strategies
$\square$ process redesign - refinements or alterations in the
production process itself
$\square$ in-process recycling - waste is reclaimed and
processed to recover a usable product, or reused
within an industrial process
$\square$ input substitution - substituting a material for one
that is less toxic or that causes less of a waste
treatment or disposal problem; also includes input
purification
$\square$ product change - redesigning the end product to
optimize material use and minimize waste
$\square$ operational efficiencies - various measures taken to
reduce waste--includes things like plant maintenance
and production practices, inventory control, employee
training, waste stream segregation, spill/leak
prevention, scheduling improvement, and the use of
computers for monitoring and analysis.
Without a specific reference in the literature to waste reduction, however, they would need to be examined in detail on a case-by-case basis to determine waste and energy effects. Therefore, the scope of this groundwork was limited to specific technologies whose principal function was waste reduction with a relatively short period for commercialization (typically 1 to 5 years). Fundamental process advantages (e.g., direct steel making), though offering potential reductions in waste and savings in energy, were not considered in this study.

\subsubsection{Summary Findings}

The literature review resulted in 590 specific technologies with positive reduction impacts for the seven industrial sectors covered. Please note that a description of the 590 technologies is available in the full report. Figure 3.1 shows a breakdown of the number of technologies logged for each sector.

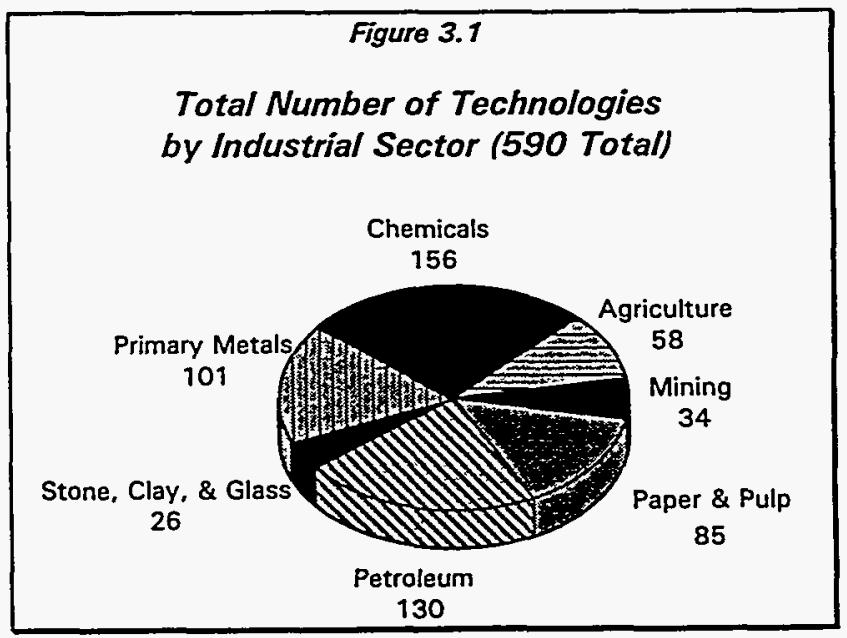


Figure 3.2 shows the number of entries by the waste reduction strategy employed. Of the technologies logged, process redesign, inprocess recycling, and operational efficiency strategies make up $87 \%$ of the total. Product change technologies found in the open literature were minimal at just $3 \%$.

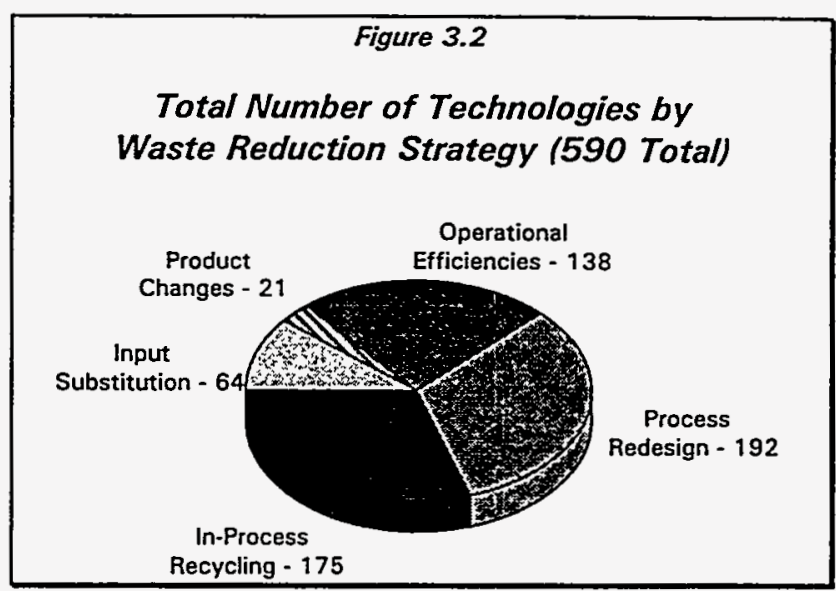

Figure 3.3 shows which of the 590 technologies included some type of quantitative information on energy impact, waste reduction, and/or costs or cost savings.

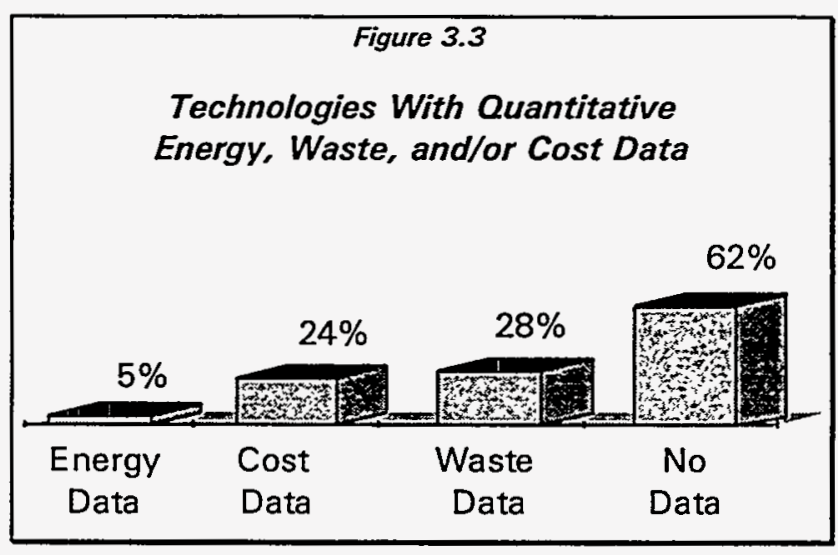

The 590 technologies were classified by industrial sector into pollution issues, and are summarized in Table 3.4. This classification suggests the pollution issues applicable to waste reduction efforts for each industry sector.

\subsubsection{Existing Technologies}

(c) (1) - assessment of the technologies available to increase productivity and simultaneously reduce the consumption of energy and material resources, and the production of wastes identified in (b)

Of the 590 total technologies recorded, 489 are existing, that is, in relatively broad use within industry (Figure 3.4 ). The existing technologies ran about 5:1 to those classified as developing technologies. Virtually all references used were 1987 or later, with the majority 1991 or later. Twenty-nine percent of the existing technologies were from the chemical industry, while only $3 \%$ were from stone, clay, and glass. This difference

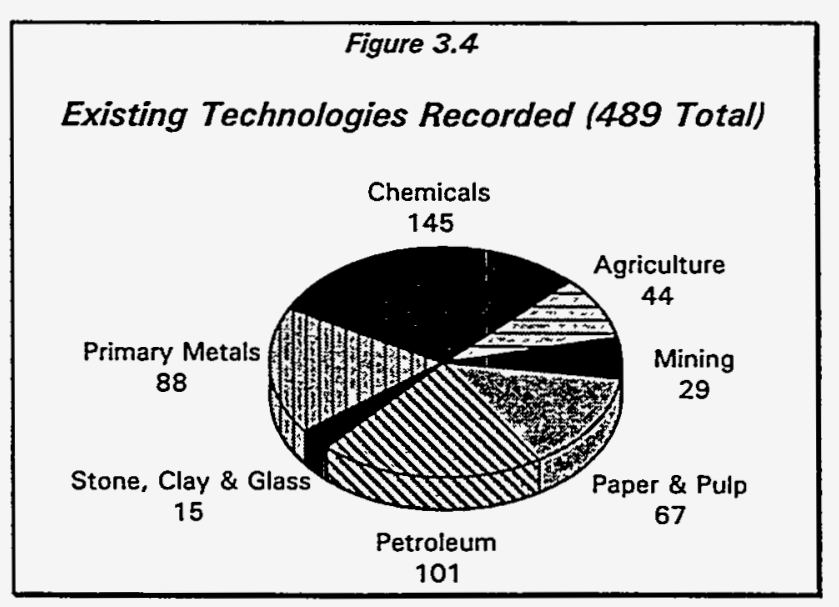

Existing Technologies Recorded 1489 Totall 
Table 3.4

Literature Review - Technology/Pollution Issue Categories - by Industry Sector

\begin{tabular}{|c|c|c|}
\hline Agriculture & $\begin{array}{l}\text { - biotechnology } * * \\
\text { - reduced dust control } \\
\text { - improved pesticide application }\end{array}$ & $\begin{array}{l}\text { - precision agriculture } * * \\
\text {-sustainable agriculture }\end{array}$ \\
\hline Mining & $\begin{array}{l}\text { - drilling and workover fluids } \\
\text { - mining through hard rock } \\
\text { - oily sludge separation } * *\end{array}$ & $\begin{array}{l}\text { - ore processing } \\
\text { - use of solvents and chemicals }\end{array}$ \\
\hline Pulp \& Paper & $\begin{array}{l}\text {-kraft pulping ** } \\
\text { - washing } \\
\text { - dry debarking } \\
\text { - delignification } \\
\text { - cooking } \\
\text { - bleaching }\end{array}$ & $\begin{array}{l}\text { - nonkraft pulping ** } \\
\text { - } \text { sulfite pulping } \\
\text { - } \text { solvent pulping } \\
\text { - mechanical pulping }\end{array}$ \\
\hline Chemical $^{5}$ & $\begin{array}{l}\text { - solvent recovery } \\
\text { - product substitution/reformulation } \\
\text {-process redesign issues }\end{array}$ & $\begin{array}{l}\text { - recycle of product containers } \\
\text { - process controls } * *\end{array}$ \\
\hline Petroleum & $\begin{array}{l}\text { - processing tank bottoms crude } * * \\
\text { - treating tail gas } \\
\text { - cooling tower blowdown } \\
\text { - spent clay processing /treatment } \\
\text { - spent caustic processing /treatment } \\
\end{array}$ & $\begin{array}{l}\text { - solvents and chemicals usage } \\
\text { - spent catalyst } \\
\text { processing/treatment } * * \\
\text { - oily sludges recovery/reprocessing } \\
\text { - sandblast media discharge }\end{array}$ \\
\hline Stone, Clay, Glass & -dust control measures & - water capture and reuse \\
\hline Primary Metals & $\begin{array}{l}\text { - case hardening baths } \\
\text { - casting sands waste reduction } \\
\text { - desulfurization } \\
\text { - dust control measures }\end{array}$ & $\begin{array}{l}\text { - metal parts cleaning } \\
\text { - pickling } \\
\text { - quenching } \\
\text { - slag management }\end{array}$ \\
\hline
\end{tabular}

- Indicates that only existing technologies were recorded for this area.

- Indicates that only developing technologies were recorded for this area.

** Indicates a technology included on one or more lists of critical technologies (Kaarsberg).

5 The chemical industry covered a large range of processes and products. As a result, further categorization was not pursued for this industry. 
may be partially explained by the fact that the chemical industry involves a larger array of processes and products than does the stone, clay, and glass sector. Unfortunately, the technologies in the literature did not provide sufficient information to assess productivity. To the extent that information was available on energy, natural resources, and wastes, it is discussed in the following sections.

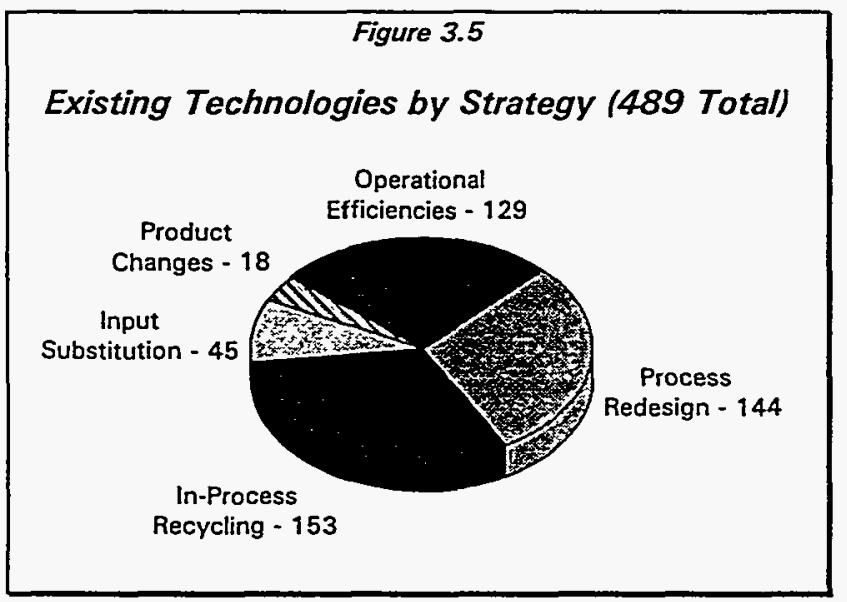

When reviewed by waste-reducing strategy application (Figure 3.5), in-process recycling, process redesign, and operational efficiencies were recorded in roughly equal numbers ( $-29 \%$ of each). There were significantly fewer product change and input substitution technologies by comparison.

The 489 existing technologies identified in the literature consisted of a broad range of technologies that were often very specific to a given industry. For example, a successful existing technology for waste reduction involves the making of a polymer by-product from the manufacture of propylene into caulking for mobile homes. 6 The estimated waste reduction of this technology was $50 \%$, capital investment was $\$ 750 \mathrm{k}$, and the annual savings was $\$ 8.7$ million (Tsuji).

\subsubsection{Current Use by Industry}

(c)(2) - assessment of the current use of such technologies by industry in the United States

In reviewing the 489 individual technologies identified herein, most are in actual use. While many technologies are detailed for a specific company or process, they may be in wider use than indicated by the source document.

In general, the adoption and ultimate use of a technology that reduces waste and saves energy are related to the following factors:

- the technology is seen as cost-effective

- the technology is known about (industry/companies aware of its existence)

- a company or industry is able to adequately assess its need for a technology

- there is no other barrier, regulatory, cultural, or otherwise, preventing its use

\footnotetext{
${ }^{6}$ There are additional examples of both existing and developing technologies described in the full report.
} 


\subsubsection{Developing Technologies and Projected Availability \\ (c)(3) - the status of any such technologies currently being developed, together with projected commercial availability}

"Developing" technologies in the literature review were defined as those still in isolated use (i.e., demonstration phase), or clearly still under development. This review found 101 such technologies (Figure 3.6). Because of the smaller set of data found, this group may not be as characteristic of industry activity as is the group of existing technologies. For example, the chemical industry at 11 technologies recorded could be interpreted to be on the same par as stone, clay, and glass, also with 11 . This is counterintuitive, however, to the significant level of technology development work

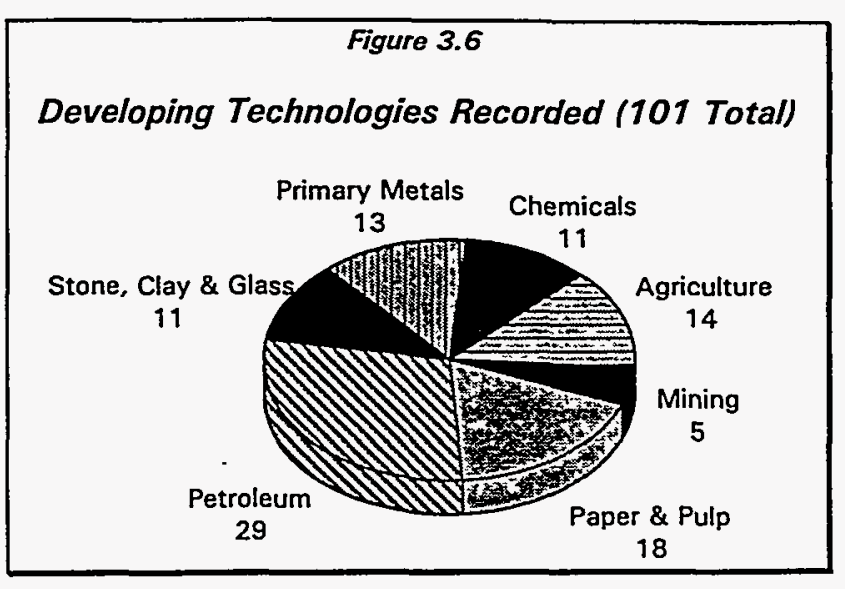
incorporating waste and energy reduction in the chemical industry.

Grouped by waste reduction strategy, nearly half of those recorded involve process redesign efforts (Figure 3.7). This suggests a strong development effort involving this strategy versus the others.

Information on commercial availability of the developing technologies identified was generally not included in the literature. In documenting the technologies, however, it was perceived that most are relatively near-term, with availability estimated to be within a one- to four-year period.

As with the existing technologies, the developing technologies tended to be very specific to a given industry. For example, a promising developing technology involves the use of a closed furnace to replace the open hearth furnace in production of silicon and ferrosilicon. Use of this technology is predicted to reduce wastes by over 0.4 million ton/yr by the year 2010, and to save 86 trillion Btu/yr of energy. This technology is expected to be commercialized within 1 to 2 years (Cranford).

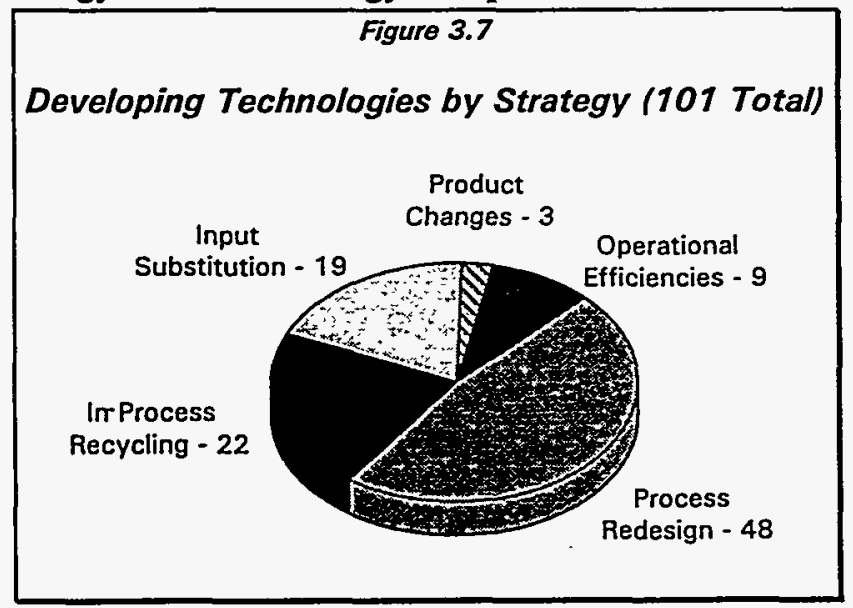

\subsubsection{Energy Savings}

(c) (4) - the energy saving resulting from the use of such technologies

As shown previously in Figure 3.3, information on energy efficiency and use was not generally included in the sources. Only 27 provided energy impact information. Of the 16 existing technologies, 14 were from the paper and pulp industry. Of the 11 developing technology sources with energy impact information, 7 are DOE/OIT Industrial Waste Program (TWP) projects, which specifically require energy reduction analysis as part of the project description. A detailed listing of these technologies is provided in the full report. 
There were eight sources providing a percentage reduction from whatever the "before" condition was. The average reduction of these eight was $31 \%$, with a range from $3 \%$ to $80 \%$. In addition, 20 sources provided annual energy savings estimates. The average of these 20 was about 3 trillion Btu/yr, even though a few registered a net energy increase. The range of energy impact for the 20 listings was from a net increase of 56 million Btu/yr, to a net savings of 86 trillion Btu/yr.

One conceivable perspective on the lack of energy impact information in the literature is

"The cost of energy usage is small (typically a few percent for most manufacturing industries) and declining, while the cost of waste disposal and associated liability costs is climbing rapidly; therefore, industry is much more interested in new technologies for waste reduction than for energy savings, even though the same technology often does both." (Kaarsberg, p. 5)

Anecdotal information on the energy savings potential from waste minimization technology development is seen in the existing projects and recent proposals of DOE's IWP:

- Even if only $20 \%$ of the current IWP portfolio of 16 projects proves successful, the estimated impact on U.S. industry energy consumption will be a reduction of 340 trillion Btu/yr by the year 2010. This savings is roughly $1.0 \%$ of the current total U.S. industrial energy usage (Cranford).

- Of industry proposals received in response to competitive solicitations issued during 1992 and 1993, 19 emerged as viable developmental opportunities. The average annual energy savings estimated per project (year 2010) was 120 trillion Btu/yr.

Not every waste reduction technology would be expected to achieve these levels of energy savings, but reasonable possibilities are shown from these examples.

\subsubsection{Environmental Benefits}

(c)(5) - the environmental benefits of such technologies

Of the 590 total entries, 497 recorded specific qualitative environmental benefits. Some of the more common benefits observed were:

- reduction in the quantity of a given waste already being produced

- substitution of a nonhazardous material for a hazardous material

- reduced toxicity of a given waste

- recovery and reuse of a previously discarded waste

- reduced use of water

- reduced air emissions

Of the 590 technologies, 117 provided an actual percentage reduction, or an estimated potential reduction in waste generation. The average reduction was $69 \%$, with a range from $3 \%$ to $100 \%$. In addition, 66 listed actual quantity predictions or measurements of waste reduced.

Also, returning to the IWP project and proposal sets identified in the last section: 
- It is estimated that the current project portfolio will reduce waste by over 42 million tons/yr by the year 2010 (again, assuming a 20\% success rate). This waste reduction is roughly $0.3 \%$ of the current total U.S. industrial wastes.

- The 19 IWP proposals have an average waste reduction forecast of 24 million tons/yr per project.

\subsubsection{Costs (and Cost Savings)}

(c)(6) - the costs of such technologies

About $24 \%$ of the technologies recorded provided some insight into the expense of implementing the technology and/or an indication of the cost savings. Capital costs for 80 technologies ranged from $\$ 17,000$ to $\$ 400$ million. Annual cost savings for 92 technologies were estimated, with three indicating a net loss of annual revenue. The technologies ranged from a net annual loss of $\$ 7.1$ million to an annual savings of $\$ 75$ million. The total annual savings to industry of these 92 entries was over $\$ 190$ million, with an average of $\$ 2.3$ million saved per year. The average payback period of 63 listings was just over three years. What can be summarized from the technologies recorded that did include cost data is that, in general, the annual savings can be significant. It must be mentioned, however, that the data set is biased in that negative cost impacts are much less likely to be documented in the open literature. Further, the fact that only one out of four technologies included information on costs suggests that it is difficult to account for all of the costs or benefits of pollution prevention, particularly indirect costs such as training or permitting or costs that cannot be predicted such as future liability costs. More information on this subject can be obtained in a recent EPA report on total cost assessment (EPA 1992b).

An example of successful cost-effective waste reduction implementation is provided in a recent literature search conducted in support of an IWP economic study on U.S. waste reduction potential (WERC 1993). The study summarized the economic benefits of 75 industrial waste minimization projects. Most involved capital or operating investments with the principal objective of reducing waste. Again, the data are biased, in that unsuccessful projects are not likely to be presented as case studies in the literature. Bias acknowledged, the study found that:

- the total annual savings of the 75-project portfolio was $\$ 34$ million,

- the average annual savings was approximately $\$ 500,000$ per company

- the average project payback was less than two years

$31 \%$ of the projects had a payback of fewer than 6 months

$86 \%$ had paybacks of 36 months or less

- $55 \%$ of the investments were under $\$ 100,000$

Furthermore, the existing IWP project portfolio is projected to improve industrial competitiveness through lowering costs by at least $\$ 2$ billion/yr (by the year $2010-20 \%$ success rate). Moreover, the IWP has found that, based on current projects and proposals, industry has a typical minimum return on investment requirement of about $15 \%$. While this certainly varies with economic conditions, degree of perceived risk, and the individual company's financial situation, it is an indicator that for investment purposes, successful waste reduction projects can provide at least this level of return for an up-front investment. 


\subsection{Evaluation of Barriers (Subsections 2108(c)(7) - (c)(8))}

(c) (7) - an evaluation of any existing Federal or State regulatory disincentives for the employment of such technologies

(c) (8) - an evaluation of any other barriers to the use of such technologies.

Table 3.5 summarizes possible barriers to adoption of waste reduction technologies derived from information in the following sources: a recent DOE report (DOE 1991b) examining the incentives and disincentives to industrial waste reduction in 16 pieces of existing legislation and their attendant regulations and in 22 pieces of proposed legislation; an EPA Office of Solid Waste (EPA 1993b) report that is still being finalized and that summarizes the barriers and incentives in 50 documents from government, academia, and industry; and a group of 60 documents, primarily journal articles, located through a literature search. In addition, three experts were contacted for information to complement that obtained in the literature.

The review on barriers to adoption of waste minimization technologies revealed the extremely complex and variant nature of a host of possible disincentives a company may face. These disincentives can be regulatory, economic, technological, organizational, or cultural. A more detailed description of these issues is contained in the full report. 


\begin{tabular}{|c|c|}
\hline \multirow{4}{*}{$\begin{array}{l}\text { Summary } \\
\text { Findings }\end{array}$} & $\kappa$ Barriers to adoption of waste minimization technologies are very complex and diverse. \\
\hline & $\begin{array}{l}\text { Environmental legislation and regulations are mostly designed to control pollution already } \\
\text { generated, rather than prevent generation. While effective at pollution control, they tend to } \\
\text { be disconnected, costly, inflexible, counter productive and inconsistently enforced, which } \\
\text { discourages innovative or voluntary actions, including waste reduction initiatives. }\end{array}$ \\
\hline & $\begin{array}{l}\kappa \text { Characteristics of a specific industry are as important as its regulatory, social, economic, } \\
\text { and cultural framework in determining an ability to develop and advance new technologies. }\end{array}$ \\
\hline & $\begin{array}{l}\kappa \text { Federal regulations can act as an incentive through costs imposed on treatment \& disposal, } \\
\text { but limited resources are often drained that can be applied to advance efficient processes. }\end{array}$ \\
\hline \multirow[t]{5}{*}{$\begin{array}{l}\text { Regulatory } \\
\text { Issues }\end{array}$} & $\begin{array}{l}\text { Federal regulations take a "command and control" approach in which strict prescriptive } \\
\text { requirements must be met with little consideration for cross-media transfer. While } \\
\text { protecting us from discharged pollutants, they provide little room for flexibility in achieving } \\
\text { compliance. The results can be to entrench existing technologies \& discourage long-term } \\
\text { innovation. }\end{array}$ \\
\hline & $\begin{array}{l}\text { RCRA has very specific requirements regarding the handling and treatment of end-of-pipe } \\
\text { pollutants that present significant obstacles to recycle, reuse, or reclamation of the waste } \\
\text { products including hazardous chemicals. }\end{array}$ \\
\hline & $\begin{array}{l}\kappa \text { Regulations requiring treatment and disposal of by-products of industrial processes within a } \\
\text { specific time frame can preclude alternative uses because of time incompatibility. }\end{array}$ \\
\hline & $\begin{array}{l}\text { The permitting process required for processes with RCRA hazardous products can be } \\
\text { difficult, lengthy, and costly. This often discourages manufacturers from instituting changes } \\
\text { that would require repermitting. }\end{array}$ \\
\hline & $\begin{array}{l}\text { There can be a cost disadvantage to a company that adopts voluntary waste reduction efforts } \\
\text { when later required by regulation to reduce further, compared to a company that has not } \\
\text { been proactive in waste reduction. }\end{array}$ \\
\hline $\begin{array}{l}\text { Federal, State } \\
\text { \& Local } \\
\text { Interactions }\end{array}$ & $\begin{array}{l}\text { The complexity of uncoordinated federal, state, and local regulations, requirements, and } \\
\text { standards increases the regulatory burden by requiring compliance with unrelated, possibly } \\
\text { inconsistent, and potentially changing requirements. This can foster the view that pollution } \\
\text { prevention is something to be handled only as required, rather than day-to-day. }\end{array}$ \\
\hline $\begin{array}{l}\text { Economic and } \\
\text { Financial }\end{array}$ & $\begin{array}{l}\kappa \text { It can be difficult to quantify the benefits of waste reduction, which then makes it difficult } \\
\text { to compete for limited capital resources. }\end{array}$ \\
\hline Technological & $\begin{array}{l}\text { Nevelopment can be long and expensive with no guarantee of payoff. Costs may be } \\
\text { burdensome, if not prohibitive, for smaller companies. }\end{array}$ \\
\hline $\begin{array}{l}\text { Management/ } \\
\text { Organization }\end{array}$ & $\begin{array}{l}\kappa \text { Management is responsible for producing a profitable and effective product. This impacts } \\
\text { decisions on adopting waste reducing technologies when the bottom line is affected. }\end{array}$ \\
\hline Cultural & $\begin{array}{l}\kappa \text { Waste reduction may be as much a cultural issue as technological. Industry, public, and } \\
\text { federal attitudes play a key role in technology implementation success and time frame. }\end{array}$ \\
\hline $\begin{array}{l}\text { Knowledge or } \\
\text { Analysis } \\
\text { Capacity }\end{array}$ & $\begin{array}{l}\text { The ability of particularly small and medium sized firms to assess ecological needs can have } \\
\text { direct bearing on the adoption of waste reducing technologies. Lack of information or } \\
\text { proper assessment capabilities can short-change technology adoption. }\end{array}$ \\
\hline $\begin{array}{l}\text { Structural } \\
\text { Factors }\end{array}$ & $\begin{array}{l}\text { Changes that have a cross-cutting effect on industries can be either positive by making new } \\
\text { opportunities for better products or for reducing costs, or negative because of the } \\
\text { dislocations produced in the existing economic situation. }\end{array}$ \\
\hline Resources & $\begin{array}{l}\text { Kack of material inputs, available capital, and people with necessary training, experience, } \\
\text { and skills are all potential barriers to the adoption of a new technology. }\end{array}$ \\
\hline Competition & $\begin{array}{l}\kappa \text { To the extent that a waste-reducing technology is differentiable from other similar products- } \\
\text {-usually either in costs or appearance--such a technology can be a barrier or an incentive. }\end{array}$ \\
\hline $\begin{array}{l}\text { Market } \\
\text { Conditions }\end{array}$ & $\begin{array}{l}\text { \% Market conditions in general will affect willingness and ability to invest in waste reduction } \\
\text { efforts versus other competing investment possibilities. }\end{array}$ \\
\hline
\end{tabular}




\section{SUMMARY OF KEY FINDINGS}

1. Industry is very diverse and complex. Because of this complexity and resource limitations, a complete assessment of energy efficient pollution preventing technology demonstration opportunities will not be concluded by October 1993. This is an ongoing activity within the DOE Industrial Waste Program.

2. Opportunities for demonstration/development of energy efficient pollution preventing technologies and processes have been identified for the chemical and petroleum industries.

3. Seven industries provide the overwhelming preponderance of waste generation, energy use, and pollution abatement expenditures. These industries--agriculture; mining, paper and pulp; chemicals; petroleum refining; stone, clay and glass; and primary metals--provide the focus for this Section 2108 response.

4. A review of the open literature supplied 590 specific existing and developing technologies with waste reduction as a principal objective. Those recorded are not an inclusive list of all technologies, but serve as a reasonable framework of current activity within the targeted industry sectors.

5. Though quantitative data on waste reduction and cost impacts were not prevalent in the open literature, those providing this type of information showed significant environmental benefits and favorable economics resulting from adoption of waste reducing technologies. Though acknowledged as a biased set of information, the potential positive effects of waste reduction are clearly demonstrated.

6. Very little information on energy efficiency impacts from waste reduction technology implementation was seen in the open literature. It is likely that energy efficiency itself is not a substantial driver for industry's implementing pollution prevention technologies, but instead is seen as an auxiliary benefit.

7. A majority of activities identified from the open literature involve redesign of the production process as a key strategy for waste reduction, particularly for technologies under development. In-process recycling and operational efficiency measures are also common strategies.

8. The forces and conditions encouraging and discouraging adoption of waste reducing technology are highly complex and interrelated. Further, while there are barriers that are identifiable across industries, there are also barriers that are industry- and even company-specific. Nontechnological barriers are fundamentally a large issue in the advancement of waste minimization business practices and technology implementation. Company-specific, public, and federal attitudes play a critical role in the ultimate success and time frame. 


\section{REFERENCES}

DOC 1993

DOE 1991a

DOE 1991b

EIA 1993

EIA 1992

EIA 1991

EPA 1993a

EPA 1993b

EPA 1992a

EPA 1992b

EPA 1991

EPA 1990

EPA 1988

EPA 1987

OSTI 1992

OTA 1992

WERC 1993

Cranford

Tsuji

Kaarsberg
Pollution Abatement Costs and Expenditures, 1991. MA-200(91)-1. Bureau of the Census, Department of Commerce. Washington, D.C.

Report of the CWRT Workshop on: Waste Reduction R\&D Opportunities in Industry, DOE/CE/40762T-H4. Office of Industrial Technologies, U.S. Department of Energy. Washington, D.C., September 1991.

Federal Legislative and Regulatory Incentives and Disincentives For Industrial Waste Reduction, Office of Industrial Technologies, U.S. Department of Energy. Washington, D.C. October 1991.

Monthly Energy Review, June 1993. DOE/EIA-0035(93/06). Energy Information Administration, U.S. Department of Energy. Washington, D.C.

1992 Annual Energy Outlook With Projections to 2010. DOE/EIA-0383(92). Energy Information Administration, U.S. Department of Energy. Washington, D.C.

Manufacturing Energy Consumption Survey: Consumption of Energy, 1988. DOE/ELA-0512(88). Energy Information Administration, U.S. Department of Energy. Washington, D.C.

National Biennial RCRA Hazardous Waste Report. EPA/530-R-92-027. Office of Solid Waste, U.S. Environmental Protection Agency. Washington, D.C.

Environmental Protection Agency. Compendium of Pollution Prevention Barriers and Incentives. (Final Draft). Office of Solid Waste and Emergency Response, U.S. Environmental Protection Agency. Washington, D.C. March, 1993. This document contains work done by ICF Incorporated under contract to the U.S. EPA Office of Solid Waste. It reflects the analysis of the contractor and does not necessarily reflect the EPA's views.

1990 Toxic Release Inventory, Public Data Release. EPA-700-S-92-002. Office of Toxic Substances, U.S. Environmental Protection Agency. Washington, D.C.

Total Cost Assessment: Accelerating Industrial Pollution Prevention through Innovative Project Financial Analysis. EPA 741-R-92-002. Office of Toxic Substances, U.S. Environmental Protection Agency.

National Air Pollutant Emissions Estimates 1940-1990. EPA-450/4-91-026. Office of Air Quality Planning and Standards, U.S. Environmental Protection Agency. Research Triangle Park, North Carolina.

Environmental Investments: The Cost of A Clean Environment. Office of Policy, Planning, and Evaluations, U.S. Environmental Protection Agency, Washington, D.C. November 1990.

Report to Congress: Solid Waste Disposal in the United States, Volumes 1 and 2. EPA/530-SW-88-011. Office of Solid Waste and Emergency Response, U.S. Environmental Protection Agency. Washington, D.C.

Report to Congress: Management of Wastes from the Exploration, Development, and Production of Crude Oil, Natural Gas, and Geothermal Energy. Volume 1. Oil and Gas. EPA/530-SW-88-003A. Office of Solid Waste and Emergency Response, U.S. Environmental Protection Agency. Washington, D.C.

Waste Reduction: An Effective Approach to Industrial Waste Management. Industrial Waste Management Technology - OSTI, June 1992.

Managing Industrial Solid Wastes From Manufacturing, Mining, Oil and Gas Production, and Utility Coal Combustion - Background Paper. OTA-BP-O-82. U.S. Office of Technology Assessment. Washington, D.C.

An Assessment of the Economic and Regulatory Factors Impacting the U.S. Industrial Waste Program. Waste Management Education \& Research Consortium, Southwest Technology Development Institute, New Mexico State University. May 1993.

Cranford, B and Eisenhauer, J., "More Jobs, Less Waste, Less Energy - U.S. DOE Industrial Waste Program" - paper given at the October 27, 1993, AEE meeting in Atlanta Georgia.

Tsuji, Karl S., Waste Reduction in the U.S. Manufacturing Sector, a Survey of Recent Trends. LA-UR 913858, Los Alamos National Laboratory, Los Alamos New Mexico, November 1991.

Kaarsberg, Tina, Ph.D., Unpublished draft report Critical Technologies and Industrial Waste Reduction: A Survey of Reports on Critical Technologies, Waste and Industry and Their Relevance to the Department of Energy's Industrial Waste Program. 
December 1993 
Distribution:

(3) Bruce Cranford

U.S. DOE

Office of Industrial Technologies/EE-222

Rm 5F043

1000 Independence Ave., SW

Washington, D.C. 20585

(1) Ken Lucien

U.S. DOE

Albuquerque Operations Office

ETD

P.O. Box 5400

Albuquerque, NM 87585-5400

(1) Kathleen Schulz, 6605

MS 0738

(15) Ed Weinbrecht, 6625

MS 0730

(1) Ted Wheelis, 6625

MS 0730

(1) Dennis Engi, 6914

MS 0729

(1) Central Technical Files, 8523-2 MS 9018

(5) Technical Library, $13414 \quad$ MS 0899

(1) Technical Publications, $12613 \quad$ MS 0619

(2) Document Processing, 7613-2 MS 0100 For DOE/OSTI

(1) Katherine Clark Tech Reps, Inc. 5000 Marble NE

Albuquerque, NM 87110 